\title{
The application of life history information to the conservation manage- ment of Chrysoritis butterflies (Lepidoptera: Lycaenidae) in South Africa
}

\author{
R.F. Terblanche and H. van HaMburg
}

Terblanche, R.F. and H. van Hamburg. 2004. The application of life history information to the conservation management of Chrysoritis butterflies (Lepidoptera: Lycaenidae) in South Africa. Koedoe 47(1): 55-65. Pretoria. ISSN 0075-6458.

Due to their intricate life histories and the unique wing patterns and colouring the butterflies of the genus Chrysoritis are of significant conservation and aesthetic value. This overview probes into practical examples of butterfly life history research applicable to environmental management of this relatively well-known invertebrate group in South Africa. Despite the pioneer work on life histories of Chrysoritis in the past, more should be done to understand the life history of the butterflies in the wild, especially their natural host plants and the behaviour of adults and larvae. A system of voucher specimens of host plants should be introduced in South Africa. Although various host plant species in nature are used by the members of Chrysoritis, including the Chrysoritis chrysaor group, the choice of these in nature by each species is significant for conservation management and in the case of Chrysoritis aureus perhaps even as a specific characteristic. A revision of the ant genus Crematogaster will benefit the conservation management of Chrysoritis species since some of these ant species may consist of a number of species with much more restricted distributions than previously thought. Rigorous quantified studies of population dynamics of Chrysoritis butterflies are absent and the introduction of such studies will benefit conservation management of these localised butterflies extensively.

Key words: Chrysoritis, myrmecophilous, endemic, conservation, life histories, management, taxonomy, ecology, synecology.

R.F. Terblanche and H. Van Hamburg, School of Environmental Sciences and Development, Private Bag X6001, Potchefstroom University for CHE, Potchefstroom, 2520 South Africa.

\section{Introduction}

Williams (1996) reported a lack of information on the life histories of South African butterflies despite the most valuable efforts of the past. Pioneer lepidopterists (including Clark, Claassens, Dickson, Cottrell, G.A. Henning, S.F. Henning and Heath) provided a rich source of life history information in the past, useful for environmental management. Further research priorities are identified here. This paper reviews the life history information on the Chrysoritis genus to date, and discusses how applicable this information is for conservation management.
World-wide, the symbioses of butterflies and ants are found only among members of the Riodinidae and Lycaenidae (De Vries 1997) and at present the Riodinidae is often regarded as a subfamily Riodininae within the Lycaenidae (Eliot 1973; Eliot 1990; Pierce et al. 2002). Although the Riodininae is poorly represented in Africa, the rest of the Lycaenidae is well-represented in most habitat types on the continent. Judging by the number of species, the majority of South African butterflies belong to the family Lycaenidae. From our list of 674 butterfly species, i.e. superfamilies Hesperioidea: 'skipper butterflies' and Papilionoidea: 'true 
butterflies' in South Africa, $49 \%$ of the species belong to the family Lycaenidae. The majority of these Lycaenidae species are associated with ants. A diversity of strategies has developed into ant associations among the Lycaenidae. Extremes, from aphytophagy (Cottrell 1984) to facultative ant associations, have been recorded. The term entomophagous is used by Pierce et al. (2002) instead of aphytophagy, which alter the normal use of entomophagous as 'insecteating' to 'eating insect-derived food sources'. Apart from the term entomophagous, all the other definitions to describe lycaenid-ant associations as defined by Pierce et al. are followed here. Note that Pierce et al. (2002) use the terms obligate and facultative ant associations in terms of survival under field conditions, which is strictly followed here.

Given the nature and complexity of larvae ant symbioses, there is much to be learnt from their studies that will be relevant to all branches of biology (De Vries 1997). The various types of associations with ants (Henning 1983a; Cottrell 1984; Pierce et al. 2002) by Lycaenidae butterflies, should be appreciated in that different conservation strategies should probably be applied to conserve these, often localised, butterflies.

\section{Discussion}

Detailed life history descriptions that entail most stages and some illustrations have only been published for $35.7 \%$ of all the Chrysoritis species in South Africa (Table 1). It should be added that ecophysiological studies of interactions between butterfly larvae and host plants as well as attendant ants are absent, not only for Chrysoritis but for almost all the butterflies of South Africa. At least one host plant and one attendant ant are known, respectively, for $83.3 \%$ and $88.1 \%$ of the Chrysoritis species. These relatively high numbers are due to the contribution of Heath (1997a) (Table 1). Dickson $(1940,1943,1944,1945 a, 1945 b, 1946$, 1947, 1948, 1953, 1959 and 1965) gave either detailed and well-illustrated (by Clark) descriptions of the life histories of some Chrysoritis species or information on the host plants and attendant ants. The first major work on the life histories of Lycaenidae butterflies of South Africa was that of Clark \& Dickson (1971) that contains a number of detailed life history descriptions. A summary of recent observations of ant associations and life history adaptations of Lycaenidae butterflies in South Africa is given by Heath \& Claassens (2000). Heath (1997) for the first time reported the extensive use of Thesium plants (Santalaceae) as host plants by Chrysoritis species. The importance of the presence of the correct ant as an oviposition stimulus for most Chrysoritis species, at least in captivity, is reported (Heath \& Claassens 2000). Clark \& Dickson (1971) concluded that Chrysoritis dicksoni is aphytophagous, since larvae refused to feed on any plant that females had laid on. The mature larvae and pupa were found in Crematogaster ant nests (Cotrell 1984). Heath \& Brinkman (1995), Heath (1998) and Heath \& Claassens (2000) demonstrated that at least in some larval stages, the larvae of Chrysoritis dicksoni are sustained by trophallaxis. Among the Chrysoritis genus trophallaxis (ants feeding caterpillars by regurgitation) has thus been reported only for Chrysoritis dicksoni by Heath (1998). The majority of the Chrysoritis species, with the possible exception of Chrysoritis dicksoni, seems to be phytophagous accompanied by an obligate ant association (Tables 1-4).

No voucher material of host plants has been cited in all the above cases. Although the genera and even some of the plant species identified leave little doubt about its identification, the lack of voucher specimens may be a limitation to future research efforts. Cottrell (1984) highlighted the problems associated with the fragmented observations of life histories of aphytophagous butterflies. These are also applicable to the ant-dependent phytophagous Chrysoritis species. Thomas et al. (1989) summarised the difficulties with the accuracy of interpretations of captive observations, the misinterpretation of field data, as well as the misidentification 
of ant species concerning research on $\mathrm{Macu}$ linea butterflies and their ant associations in Europe.

The question is whether quantitative laboratory-controlled observations and careful observations in the field concerning the life histories of Chrysoritis species are available or not. Most Chrysoritis species were bred in captivity (where behaviour and requirements are abnormal). Therefore little information exists under controlled conditions or in the field. We discuss the present knowledge of the host plant association and attendant ant association separately for simplicity.

\section{The host plant association}

A summary of the host plant genera, host plant families, and attendant ant genera associated with the species groups of Chrysoritis is given in Table 2. Chrysoritis species have adapted to use a variety of host plants from different genera and families as larval food (Table 2). Different species groups share some genera and families. The ability of some species to use succulents of the family Crassulaceae as host plants gives rise to the hypothesis that such host plants may have been important for the survival of these butterflies especially during dry spells. The full significance of the use of host plants will only become apparent if more research on their use in specific ecosystems were conducted. Another research priority is that some host plants for the Chrysoritis species need confirmation. Chrysoritis chrysaor was observed to oviposit on Acacia karroo (Heath 1997), but it is not clear whether the larvae use these trees as a host plant. During research on Chrysoritis aureus from 1998 to 2002, it was found that the females often oviposit on rocks close to the host plant and in fact close to the attendant ant trails (Roos $\&$ Henning 2000). The proof for the use of a specific host plant remains the larvae eating the host plant in its habitat. The type of observation (egg laying, larva at base of host plant) about the host plant should be stated clearly in publications. The significance of the host plants on a taxonomic and ecologi- cal level is discussed by using Chrysoritis aureus as an example.

Heath (2001) demonstrated that the choice of larval host plant is not a major issue within a species group of Chrysoritis and should not be regarded as a specific characteristic. The variety of host plants used by Chrysoritis, even in the same species group such as the Chrysoritis chrysaor species group seems to support this hypothesis. Pierce (1984) proposed two ways by which ant association could have enhanced diversification of the Lycaenidae, once it evolved. The first is by inducing a higher incidence of host plant switching and the second is by modifying the butterfly population structure. An example in Chrysoritis is the observation that Chrysoritis aethon larva used a Crassula species as host plant, and not only the known host plant Rhus zeyheri (Anacardiaceae), that was reported by Owen-Johnston (1991). This phenomenon should be further investigated since it might be ecologically significant. Heath (2001) states that Chrysoritis aureus has been successfully bred in captivity on another plant, Diospyros lycioides, an important observation in the context of the Chrysoritis chrysaor species group to which Chrysoritis aureus belongs. Up to date, Clutia pulchella individuals were observed as host plants of Chrysoritis aureus larvae in the field. Only once (17 March 2004) was Diospyros lyciodes observed to be a host plant, despite its presence at many of our research sample plots. Clutia pulchella has a wide distribution in the northern provinces of South Africa (Retief \& Herman 1997) as well as South Africa (Arnold \& De Wet 1993) but is not used by any Chrysoritis species other than Chrysoritis aureus. The only Euphorbiaceae plant known to be utilised by any Chrysoritis species is Clutia pulchella. It is utilised by larvae of Chrysoritis aureus (Tables 2 and 3). The unidentified Morgenzon Chrysoritis entity, as well as Chrysoritis lyncurium (closely related to Chrysoritis aureus within the Chrysoritis chrysaor species group), is also thought to use Diospyros as a host plant (Owen-Johnston 1991). This has been assumed from the adult behaviour and has 
Table 1

A summary of the life-history studies published on Chrysoritis. The types of descriptions $(A, B, C)$ include: $A$ - a description of all or some of the stages (from egg to adult), $B$ - the host plant has been reported, $C$ - the attendant ant has been reported. The literature sources are those that reported previously unknown aspects of the life-histories. The literature sources used were, Dickson (1940, 1943, 1944, 1945a, 1945b, 1946, 1947, 1948, 1953, 1959, 1965), Clark and Dickson (1971), Dickson and Kroon (1978), S.F. Henning (1983a), Owen-Johnston (1991), Heath and Brinkman (1995), Heath (1997a), Heath (1998), Claassens (2000) and Heath (2001)

\begin{tabular}{lll}
\hline Chrysoritis Species & Description & Literature \\
& A B C & \\
\hline
\end{tabular}

\section{Chrysaor Species Group}

Chrysoritis aethon

(Trimen \& Bowker, 1887)

Chrysoritis aureus (Van Son, 1966)

Chrysoritis chrysaor (Trimen, 1864)

Chrysoritis lycegenes (Trimen, 1874)

Chrysoritis lyncurium (Trimen, 1868)

Chrysoritis midas (Pennington, 1962)

Chrysoritis natalensis (Van Son, 1966)

Chrysoritis phosphor (Trimen, 1866)

\section{Chrysantas Species Group}

Chrysoritis chrysantas (Trimen, 1868)

\section{Oreas Species Group}

Chrysoritis dicksoni (Gabriel, 1946)

Chrysoritis oreas (Trimen, 1891)

\section{Zeuxo Species Group}

Chrysoritis zeuxo (Linnaeus, 1764)

Chrysoritis zonarius (Riley, 1938)

\section{Pyroeis Species Group}

Chrysoritis felthami (Trimen, 1904)

Chrysoritis pyroeis (Trimen, 1864)

\section{Thysbe Species Group}

Chrysoritis adonis (Pennington, 1962)

Chrysoritis aridus (Pennington, 1953)

Chrysoritis azurius (Swanepoel, 1975)

Chrysoritis beaufortius (Dickson, 1966)

Chrysoritis beulah (Quickelberge, 1966)

Chrysoritis blencathrae

(Heath and Ball, 1992)

Chrysoritis braueri (Pennington, 1967)

Chrysoritis brooksi (Riley, 1938)

Chrysoritis daphne (Dickson, 1975)

Chrysoritis endymion (Pennington, 1962)

Chrysoritis irene (Pennington, 1968)

Chrysoritis nigricans (Aurivillius, 1924)

Chrysoritis orientalis (Swanepoel, 1976) Chrysoritis palmus (Stoll, 1781)

Chrysoritis pan (Pennington, 1962)

Chrysoritis pelion (Pennington, 1953)

Chrysoritis penningtoni (Riley, 1938)

Chrysoritis perseus (Henning, 1977)
11 Owen-Johnston (1991)

$1 \quad 1 \quad 1$ Henning (1983a)

111 Dickson (1943), Dickson (1944), Heath(1997a), Claassens (2000)

111 Clark \& Dickson (1971), Henning (1983a)

1 Heath (1997a)

11 Heath (1997a)

1 Dickson \& Kroon (1978)

$--$

111 Dickson (1953), Dickson (1975), Clark \& Dickson (1971), Heath (1997a)

$1 \quad 1 \quad 1 \quad$ Heath (1997a), Claassens (2000)

111 Dickson (1940), Clark \& Dickson (1971), Heath (1997a), Claassens (2000)

111 *Dickson (1948), Clark \& Dickson (1971), Heath (1997a), Claassens (2000)

111 Dickson (1965), Clark \& Dickson (1971), Heath (1997a)

11 Dickson (1965), Clark \& Dickson (1971)

$-\frac{1}{1}$ Heath (1997a)

$-\overline{1}$ Heath (1997a)

111 Clark \& Dickson (1971), Heath (1997a)

11 Dickson (1959), Clark \& Dickson (1971), Heath (1997a)

11 Heath (1997a)

11 Heath (1997a)

$\mp \mp \overline{1}$ Dickson (1944), Dickson (1947), Clark \& Dickson (1971), Heath (1997a), Claassens (2000)

11 Heath (1997a)

111 Dickson (1945a,1945b), Dickson (1953), Dickson (1965), Clark \& Dickson (1971), Claassens (2000)

$111 * *$ Dickson (1965), **Clark \& Dickson (1971), Heath (1997a)

- - - Heath (1997a)

$1 \quad 1$ Heath (1997a) 
Table 1 (continued)

\begin{tabular}{lrrrrl}
\hline Chrysoritis Species & Description & Literature \\
& A & B & C & \\
\hline Chrysoritis plutus (Pennington, 1976) & & 1 & 1 & Heath (1997a) \\
Chrysoritis pyramus (Pennington, 1953) & & 1 & 1 & Heath (1997a) \\
Chrysoritis rileyi (Dickson, 1966) & & 1 & 1 & Heath (1997a) \\
Chrysoritis swanepoeli (Dickson, 1965) & & 1 & 1 & Heath (1997a) \\
Chrysoritis thysbe (Linnaeus, 1764) & 1 & 1 & 1 & Dickson (1947), Dickson (1965), Clark \& Dickson (1971), Heath \\
& & & & (1997a), Claassens (2000) \\
Chrysoritis trimeni (Riley, 1938) & & 1 & 1 & Heath (1997a) \\
Chrysoritis turneri (Riley, 1938) & & 1 & 1 & Dickson (1953); Heath (1997a) \\
Chrysoritis uranus (Pennington, 1962) & 1 & 1 & 1 & Dickson (1965), Clark \& Dickson (1971), Heath (1997a) \\
Chrysoritis violescens (Dickson, 1971) & & 1 & 1 & Heath (1997a) \\
\hline TOTAL & 15 & 35 & 37 & \\
Percentage Of Total Species & 35.7 & 83.3 & 88.1
\end{tabular}

* See Heath (1997a) that the Camponotus associate that Dickson reported was never repeated

** Note this was observed for Chrysoritis lysander (now regarded as synonym of Chrysoritis pan by Heath (2001).

not been verified. An alternative explanation is that Diospyros lycioides is an ancestral host plant for Chrysoritis lyncurium, Chrysoritis lycegenes, the Morgenzon Chrysoritis entity, as well as Chrysoritis aureus and Chrysoritis aethon - all belonging to the Chrysoritis chrysaor species group. In general, it is common practice for lepidopterists to use substitute host plants for breeding butterflies, plants that may not necessarily be used in the wild. Although various host plant species are used by the members of Chrysoritis, including the Chrysoritis chrysaor group, the choice of these, in nature, by each species is significant for conservation management, in the case of Chrysoritis aureus perhaps even as a specific characteristic. The proper management of Clutia pulchella at the habitats of Chrysoritis aureus would be very important for the survival of the butterfly in its increasingly urbanised distribution. In the light of the above it is furthermore significant that Chrysoritis aureus is the only Chrysoritis species apart from the ubiquitous Chrysoritis chrysaor that extended its distribution into the Rocky Highveld Grassland via Clutia pulchella and its attendant ant (Bredenkamp \& Van Rooyen 1996).

\section{The ant association}

For a number of Chrysoritis species, the attendant ant is perhaps of more importance than the host plant as a signal for the female to lay eggs (Heath 1997, 2001). Various adaptations and strategies exist among the rich myrmecophilous lycaenid fauna of Africa, of which various are described by S.F. Henning (1983a) and Cottrell (1984). During the day, Chrysoritis larvae shelter for protection and only venture forth at night to feed on their host plants (Henning 1987a). Although the morphological and physiological adaptations among the myrmecophilous larvae have been described, the role of these has been more difficult to demonstrate. There are a number of accessory structures that are associated with larvae that adopted a myrmecophilous life style. Most lycaenid larvae have a median dorsal organ (honey gland) (Henning 1983a), which is referred to as a dorsal nectary organ (DNO) by Cotrell (1984). These are present in all the Chrysoritis larvae studied up to date. A pair of dorsolateral eversible organs is also found on many lycaenid larvae (Henning 1983a). These are referred to as tubercle organs (TOs) by Cottrell (1984) and are also found on all the larvae of Chrysoritis studied to 
Table 2

Summary of the host plant genera, host plant families and attendant ant genera associated with the different species groups of Chrysoritis. The literature sources: Dickson (1940, 1943, 1944, 1945a, 1945b, 1946 , 1947, 1948, 1953, 1959, 1965), Clark \& Dickson (1971), Dickson \& Kroon (1978), S.F. Henning (1983a), Owen-Johnston (1991), Heath \& Brinkman (1995), Heath (1997a), Heath (1998), Claassens (2000) and Heath (2001). Plant genera and families are in alphabetic order

\begin{tabular}{|c|c|c|c|c|}
\hline & $\begin{array}{c}\text { No. of species: } \\
\text { Heath (2001) }\end{array}$ & $\begin{array}{l}\text { Known host } \\
\text { plant genera }\end{array}$ & $\begin{array}{l}\text { Known host } \\
\text { plant families }\end{array}$ & $\begin{array}{c}\text { Host ant } \\
\text { Genera }\end{array}$ \\
\hline C. chrysaor sp. group & 8 & $\begin{array}{l}\text { Acacia } \\
\text { Clutia } \\
\text { Chrysanthemoides } \\
\text { Cotyledon } \\
\text { Diospyros } \\
\text { Myrsine } \\
\text { Rhus } \\
\text { Tylecodon } \\
\text { Zygophyllum }\end{array}$ & $\begin{array}{l}\text { Anacardiaceae } \\
\text { Asteraceae } \\
\text { Crassulaceae } \\
\text { Ebenaceae } \\
\text { Euphorbiaceae } \\
\text { Fabaceae } \\
\text { Myrsinaceae } \\
\text { Zygophyllaceae }\end{array}$ & Crematogaster \\
\hline C. chrysantas sp. group & 1 & Unknown & Unknown & Unknown \\
\hline C. oreas sp. group & 2 & Thesium $^{l}$ & Santalaceae $^{l}$ & $\begin{array}{l}\text { Crematogaster } \\
\text { Myrmicaria }\end{array}$ \\
\hline C. zеuxo sp. group & 2 & Chrysanthemoides & Asteraceae & Crematogaster \\
\hline C. pyroeis sp. group & 2 & $\begin{array}{l}\text { Zygophyllum } \\
\text { Thesium }\end{array}$ & $\begin{array}{l}\text { Zygophyllaceae } \\
\text { Santalaceae }\end{array}$ & $\begin{array}{l}\text { Crematogaster } \\
\text { Myrmicaria }\end{array}$ \\
\hline C. thysbe sp. group & 27 & $\begin{array}{l}\text { Aspalathus } \\
\text { Berzelia } \\
\text { Centella } \\
\text { Chrysanthemoides } \\
\text { Dimorphotheca } \\
\text { Lebeckia } \\
\text { Osteospermum } \\
\text { Thesium } \\
\text { Tylecodon } \\
\text { Zygophyllum }\end{array}$ & $\begin{array}{l}\text { Apiaceae } \\
\text { Asteraceae } \\
\text { Bruniaceae } \\
\text { Crassulaceae } \\
\text { Fabaceae } \\
\text { Myrsinaceae } \\
\text { Santalaceae } \\
\text { Zygophyllaceae }\end{array}$ & Crematogaster \\
\hline
\end{tabular}

('Perhaps no plant utilised in the case of Chrysoritis dicksoni)

date. These organs tend to be important with regard to the ant associations as defined by Pierce et al. (2002). In the case of Chrysoritis aureus, the anterior part of the head of the Cremagaster liengmei ant sometimes disappears into the DNO in search of the nectar produced by the larvae. Furthermore, the inner part of the tubercles is often eversed in the presence of the ants or to 'attract the attention of the ants'. The above studies emphasise the extent to which these butterfly larvae are adapted for ant associations. In the case of Aloeides dentatis Henning (1983b) found that epidermal glands (pore copula organs) have a secretion that mimics the brood pheromone of the attendant ant. Such detailed studies have not yet been published on any of the Chrysoritis.

Audible squeaking sounds, produced by pupae of Chrysoritis brooksi (Schlosz \& Schlosz 1990) and Chrysoritis irene (Schlosz 1991), might be of ecological significance and should be studied further. Drumming sounds from the larvae of Chrysoritis dicksoni and Chrysoritis thysbe were recorded by Heath (1998). De Vries (1990, 1992) has provided detailed descriptions and research techniques that detected audible rituals and other accessories that enhance symbiotic 
Table 3

Summary of the host plants used by species belonging to the C. chrysaor species group in the genus

Chrysoritis and the literature source where the host plant was first reported.

${ }^{a}$ Larvae were bred on the plant in captivity or in the laboratory.

a Only oviposition on the plant observed (Heath 1997).

aaa Larvae or pupae were observed on or at the base of the host plant in the field

\begin{tabular}{|c|c|c|c|c|}
\hline Species & $\begin{array}{l}\text { Plant Species } \\
\text { with indication of } \\
\text { type of observation }\end{array}$ & Plant Family & Literature Source & $\begin{array}{l}\text { Information } \\
\text { About } \\
\text { Voucher } \\
\text { Specimens }\end{array}$ \\
\hline $\begin{array}{l}\text { Chrysoritis } \\
\text { aethon (Trimen } \\
\text { \& Bowker, 1887) }\end{array}$ & $\begin{array}{l}\text { Rhus zeyheri aaa } \\
\text { Crassula } \text { sp. aaa }\end{array}$ & $\begin{array}{l}\text { Anacardiaceae } \\
\text { Crassulaceae }\end{array}$ & $\begin{array}{l}\text { Owen-Johnston (1991) } \\
\text { Heath (2001) }\end{array}$ & $\begin{array}{l}\text { No voucher } \\
\text { material sited }\end{array}$ \\
\hline $\begin{array}{l}\text { Chrysoritis } \\
\text { aureus } \\
\text { (Van Son, 1966) }\end{array}$ & $\begin{array}{l}\text { Clutia pulchella aaa } \\
\text { Diospyros lycioides a }\end{array}$ & $\begin{array}{l}\text { Euphorbiaceae } \\
\text { Ebenaceae }\end{array}$ & $\begin{array}{l}\text { Henning (1983) } \\
\text { Heath (2001) }\end{array}$ & $\begin{array}{l}\text { No voucher } \\
\text { material sited }\end{array}$ \\
\hline $\begin{array}{l}\text { Chrysoritis } \\
\text { chrysaor } \\
\text { (Trimen, 1864) }\end{array}$ & $\begin{array}{l}\text { Cotyledon orbiculata } \mathrm{L} \text {. aaa } \\
\text { Rhus sp. aaa } \\
\text { Acacia karroo aa } \\
\text { Zygophyllum retrofractum aa } \\
\text { Tylecodon paniculata aa }\end{array}$ & $\begin{array}{l}\text { Crassulaceae } \\
\text { Anacardiaceae } \\
\text { Fabaceae } \\
\text { Zygophyllaceae } \\
\text { Crassulaceae. }\end{array}$ & $\begin{array}{l}\text { Dickson }(1943) \\
\text { Dickson }(1943) \\
\text { Heath }(1997 \mathrm{a} \\
\text { Heath }(1997 \mathrm{a}) \\
\text { Heath }(1997 \mathrm{a})^{\#}\end{array}$ & $\begin{array}{l}\text { No voucher } \\
\text { material sited }\end{array}$ \\
\hline $\begin{array}{l}\text { Chrysoritis } \\
\text { lycegenes } \\
\text { (Trimen, 1874) }\end{array}$ & $\begin{array}{l}\text { Royena hirsuta aaa } \\
\text { Myrsine africana aaa } \\
\text { Diospyros lycioides aaa } \\
\text { Diospyros austro-africana aaa } \\
\text { Rhus sp. aaa }\end{array}$ & $\begin{array}{l}\text { Ebenaceae } \\
\text { Myrsinaceae } \\
\text { Ebenaceae } \\
\text { Ebenaceae } \\
\text { Anacardiaceae }\end{array}$ & $\begin{array}{l}\text { Clark \& Dickson 1971) } \\
\text { Clark \& Dickson (1971) } \\
\text { Henning (1983a) } \\
\text { Henning (1983a) } \\
\text { Henning (1983a) }\end{array}$ & $\begin{array}{l}\text { No voucher } \\
\text { material sited }\end{array}$ \\
\hline $\begin{array}{l}\text { Chrysoritis } \\
\text { lyncurium } \\
\text { (Trimen, 1868) }\end{array}$ & not confirmed & not confirmed & & \\
\hline $\begin{array}{l}\text { Chrysoritis } \\
\text { midas } \\
\text { (Pennington, 1962) }\end{array}$ & Diospyros austro-africana & Ebenaceae & Heath (1997a) & $\begin{array}{l}\text { No voucher } \\
\text { material sited }\end{array}$ \\
\hline $\begin{array}{l}\text { Chrysoritis } \\
\text { natalensis } \\
\text { (Van Son, 1966) }\end{array}$ & $\begin{array}{l}\text { Chrysanthemoides monilifera } \\
\text { Cotyledon orbiculata } \\
\text { (No reference to observations) }\end{array}$ & $\begin{array}{l}\text { Asteraceae } \\
\text { Crassulaceae }\end{array}$ & $\begin{array}{l}\text { Dickson \& Kroon (1978) } \\
\text { Dickson \& Kroon (1978) }\end{array}$ & $\begin{array}{l}\text { No voucher } \\
\text { material sited }\end{array}$ \\
\hline $\begin{array}{l}\text { Chrysoritis } \\
\text { phosphor } \\
\text { (Trimen, 1866) }\end{array}$ & Unknown & Unknown & & \\
\hline
\end{tabular}

\#Note this information is for the entity Chrysoritis lycia (Riley, 1938), which is now regarded as a synonym of Chrysoritis chrysaor by Heath (2001).

associations between Riodininae larvae and ants. At present, no such detailed research exists for any of the African Lycaenidae.

A number of instances have been reported where Chrysoritis species have been bred in captivity in the absence of ants. Nevertheless, in the field the association seems to be vital. The latter confirms the importance of observations in the field - associations that may not be essential for survival in the laboratory might be obligatory in the field. Most of the Chrysoritis species fall into the category of phytophagous, but with a myrmecophily, where the butterfly is dependent on ants (see Henning 1983a). 
The reasons for the evolution of ant associations are discussed by Cottrell (1984), especially whether these associations are for protection from parasites and predators (Thomann 1901) or to avoid ant aggression (Lenz 1917). Quantitative and controlled observations in this regard are also rare. Cottrell (1984) suggests that both factors had differing and probably complementary parts to play in different taxonomic groups within the Lycaenidae. Evidence that the presence of ants associated with myrmecophilous butterflies reduces the risk of attack from predators and parasites are provided by Pierce \& Mead (1981) and Pierce et al. (1987). Pierce et al. (2002) provides an overview of costs and benefits of lycaenid-ant interactions. Specific detailed experiments of the South African fauna seem to be absent, and seems to be important for conservation since the importance of ant protection seems to vary among species (see Pierce et al. 2002).

Despite the variety of host plants used by the Chrysoritis species (Tables $2 \& 3$ ), only ants of the subfamily Myrmicinae are used as attendant ants (Table 4). The larvae of Chrysoritis aureus are constantly attended by Crematogaster ants (Henning 1983a). The ant genus Crematogaster is a large genus of small, monomorphic, blackish or brownish-yellow ants of which at least 50 species have been described from southern Africa. They occur from the Cape to Ethiopia (Prins 1978). It is interesting to note that the Chrysoritis genus is confined to the south-western and south-eastern parts of South Africa, despite the ability to use various host plants and being associated with Crematogaster ants, of which numerous species are widely distributed in Africa. Perhaps the various other Aphnaeini (Lycaenidae: Theclinae) butterflies that are also associated with Crematogaster ants might be better adapted to savanna and forest ecosystems than Chrysoritis species.

Heath (2001) noted the importance of ant associates in the systematics of the genus Chrysoritis as well as the possibility that the ant species are themselves composed of species groups that should not be over- looked. The importance of Crematogaster liengmei and Crematogaster peringueyi as attendant ants can be appreciated for the Chrysoritis chrysaor species group (Table 4). Both these ant species are also attendant ants for Chrysoritis species that belong to other species groups (see Heath 2001). Therefore, the correct Crematogaster species in each case, that seems to be essential for the survival of these butterflies may be less widespread than is currently understood. The implication of Heath's observation is that a revision of the Crematogaster ant species will benefit the conservation management of Chrysoritis species.

In the absence of ants, a fungal infection occurs in the dorsal nectary organ and the larva usually dies after a few days ( Henning 1987; Roos \& Henning 2000; Terblanche et al. 2003). All the larval instars of Chrysoritis aureus, as well as the pupae in the ant nest were observed to be accompanied by at least two but often more Crematogaster liengmei individuals. This was found every time that larvae or pupae were observed during the field work done in the wet seasons of 2000-2004 by R.F. Terblanche in the Heidelberg district of South Africa. When an ant nest underneath a rock contained pupae, it was carefully turned over (Fig. 1), the Crematogaster liengmei individuals were observed to lift their gasters and some would position themselves on the dorsal part of the pupae. In these cases the ants that rarely bite when disturbed, now did so fiercely. The pupae, and not only larvae, seem to be protected, but the mechanisms of the pupa to enhance protection seem to be poorly studied. The presence of larvae and especially pupae in the ant nests could be a response to a variety of unfavourable factors, such as mammalian grazing and trampling pressures, frost and fire (Cottrell 1984). Although these factors make sense considering for example the field observations on Chrysoritis aureus, Cottrell (1984) noted that such explanations should be based on much more detailed quantitative studies of individual lycaenid biology. 
Brussard (1991) and New (1997) verified the importance of detailed auto-ecological information. New (1997) noted the importance of studying butterfly population dynamics at least for a number of seasons, but also mentioned that the duration of the studies or urgency sometimes permits for one flight season only, or sometimes even less. Heath \& Brinkman (1995) have described aspects of the population dynamics of Chrysoritis dicksoni based on collections and observations in the field. No published literature could, however, be found where the size or the abundance of the colonies of Chrysoritis had been measured or quantified with the aid of sample plots, transects or any well-described mark-andrecapture procedure. In fact, few population studies have been published for any of the myrmecophilous Lycaenidae of Southern Africa. An unpublished report by De Wet (1992) on the butterfly Erikssonia acraeina contains numbers and sex ratios.

\section{Conclusions}

Pioneer lepidopterists (including Clark, Claassens, Dickson, Cottrell, G.A.Henning, S.F. Henning and Heath) provided a rich source of life history information in the past which in the end is a source of information for environmental management. This paper indicates that much more should be done to understand the life history of the butterflies in the wild, especially their natural host plants and the behaviour of adults and larvae. The circumstances and types of associations with host plants and

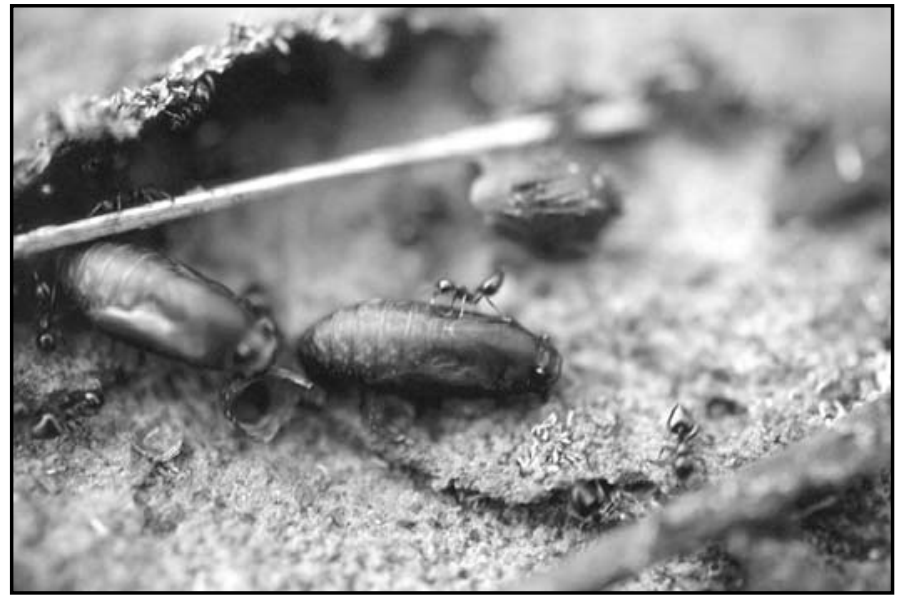

Fig. 1. Wall of ant nest with pupae and attendant Crematogaster liengmei ants.

attendant ants should be more precisely described so that traceability and repeatability could be enhanced. Experiments of microclimate on the morphology of Chrysoritis species should be described in detail, as well as the results, if one were to prove the relevant hypotheses. No system of voucher specimens of host plants exists in South Africa. Such a system would enhance the traceability of host plant information, especially if taxonomic changes regarding the plants have taken place. Fish (1999) gives clear guidelines on the preparation of herbarium specimens that are recommended to study the life histories of butterflies.

The physiological interactions during the life cycle of myrmecophilous butterflies with their attendant ants and host plants in South Africa are unknown for Chrysoritis species (and also for all the Lycaenidae in Southern Africa). The research will therefore most probably be rewarding.

Much remains to be done to quantify the population dynamics of Chrysoritis species and in fact all the localised butterflies in Africa. Although it would prove to be very difficult, efforts should also be made to quantify predation and competition, or at least make an effort to do so. The use of alternatives for mark-and-recapture methods, such as transecting methods, is a research field worth exploring in Africa. A better idea of dispersal behaviour of Chrysoritis butterflies would enhance the 
understanding of distribution, population dynamics and especially metapopulations.

\section{References}

Arnold, T.H. \& B.C. DE Wet (eds.). 1993. Plants of Southern Africa: names and distribution. Memoirs of the botanical survey of South Africa No. 62.

BREDenKamp, G.J. \& N. van Rooyen. 1996. Rocky Highveld grassland. P. 39. In: Low, A.B. \& A.G. Rebelo (eds.). Vegetation of South Africa, Lesotho and Swaziland. Pretoria: Department of Environmental Affairs \& Tourism.

BRUSSARD, P.F. 1991. The role of ecology in biological conservation. Ecological Applications 1(1): 6-12.

Claassens, A.J.M. 2000. The butterflies of the Cape Peninsula: a comprehensive guide. Cape Town: Tafelberg.

Clark, G.C. \& C.G.C. Dickson. 1971. Life histories of the South African lycaenid butterflies. Cape Town: Purnell.

CotTrell, C.B. 1984. Aphytophagy in butterflies: its relationships to myrmecophily. Zoological Journal of the Linnean Society 79: 1-57.

DE VRIES, P.J. 1990. Enhancement of symbiosis between butterfly caterpillars and ants by vibrational communication. Science 248(4959): 1104-1106.

DE VRIES, P.J. 1992. Singing caterpillars, ants and symbiosis. Scientific American (Oct.): 56-62.

DE VRIES, P.J. 1997. The butterflies of Costa Rica and their natural history. Vol. II Riodinidae. NJ: Princeton University Press.

DE Wet, J.I. 1992. Die bewaring van die skoenlapper Erikssonia acraeina in die Waterberg. Interne verslag. (Projek TK 3. Eerste vorderingsverslag. Hoofdirektoraat: Natuur- en Omgewingsbewaring, Invertebraatseksie, Lydenburg).

DiCKSON, C.G.C. 1940. Notes on the early stages of Phasis felthami (Trim.), a lycaenid butterfly from the Cape Peninsula, and a list of some recently determined foodplants of some other South African butterflies. Annals of the South African Museum 32 (6): 545-554.

DiCKSON, C.G.C. 1943. The life-history of Phasis chrysaor (Trim.) (Lepidoptera: Lycaenidae). Journal of the Entomological Society of Southern Africa 6: 37-47.

Dickson, C.G.C. 1944. Recently observed foodplants of some Cape lepidopterous larvae (1st series). Journal of the Entomological Society of Southern Africa 7: 96-99.

Dickson, C.G.C. 1945a. The life-history of Phasis palmus (Cram.) (Lepidoptera: Lycaenidae).
Journal of the Entomological Society of Southern Africa 8: 99-110.

Dickson, C.G.C. 1945b. Recently observed foodplants of some Cape lepidopterous larvae (2nd series). Journal of the Entomological Society of Southern Africa 8: 150-153.

Dickson, C.G.C. 1946. The life-history of Phasis thysbe L. var. nigricans Aurivillius (Lepidoptera: Lycaenidae). Journal of the Entomological Society of Southern Africa 9: 178-192.

Dickson, C.G.C. 1947. Recently observed foodplants of some Cape lepidopterous larvae (3rd series). Journal of the Entomological Society of Southern Africa 10:126-130.

Dickson, C.G.C. 1948. The life-history of Phasis pyroeis (Trim.) (Lepidoptera: Lycaenidae). Journal of the Entomological Society of Southern Africa 11: 99-110.

Dickson, C.G.C. 1953. Recently observed foodplants of some Cape lepidopterous larvae (4th series). Journal of the Entomological Society of Southern Africa 15(1): 11-20.

DiCKson, C.G.C. 1959. Notes on the early stages of Poecilmitis brooksi (Riley) (Lepidoptera: Lycaenidae). Journal of the Entomological Society of Southern Africa 22 (2): 312-315.

Dickson, C.G.C. 1965. Recently observed foodplants of some South African lepidopterous larvae (5th series). Journal of the Entomological Society Southern Africa 28(1): 11-20.

Dickson, C.G.C. \& D.M. Kroon (eds.). 1978. Pennington's butterflies of Southern Africa. Johannesburg: AD. Donker.

ELLIOT, J.N. 1973. The higher classification of the Lycaenidae (Lepidoptera): a tentative arrangement. Bulletin of the British Museum of Natural History (Entomology) 28:371-505.

ElLiot, J.N. 1990. Notes on the genus Curetis Hübner (Lepidoptera, Lycaenidae). Tyô to $G a$ 41: 201-225.

Fish, L. 1999. Preparing herbarium specimens. Strelitzia 7: 1-57.

Heath, A. 1997. A review of African genera of the tribe Aphnaeini (Lepidoptera: Lycaenidae). Metamorphosis: occasional supplement 2: 1-60.

Heath, A. 1998. Further aspects on the life history of the myrmecophilous species Chrysoritis dicksoni (Gabriel), (Lepidoptera: Lycaenidae). Metamorphosis 9(4): 160-172.

HeAth, A. 2001. New synonymies and taxonomic notes on the genus Chrysoritis (Butler) (Lepidoptera: Lycaenidae). Metamorphosis 12 (3): 85-98.

Heath, A. \& A.K. Brinkman. 1995. Aspects of the life history, distribution and population fluctuations of Oxychaeta dicksoni (Gabriel) (Lepidoptera Lycaenidae). Metamorphosis 6(3): 117-127. 
Heath, A. \& A.J.M. ClaAssens. 2000. New observations of ant associations and life history adaptations (Lepidoptera: Lycaenidae) in South Africa. Metamorphosis 11(1): 3-19.

Henning, S.F. 1983a. Biological groups within the Lycaenidae (Lepidoptera). Journal of the Entomological Society of Southern Africa, 46(1): 65-85.

Henning, S.F. 1983b. Chemical communication between lycaenidae larvae (Lepidoptera: Lycaenidae) and ants (Hymenoptera: Formicidae). Journal of the Entomological Society of Southern Africa 46(1): 65-85.

Henning, S.F. 1987. Myrmecophilous Lycaenidae (or How ants help butterflies). South African Journal of Science 83: 8-9.

LENZ, F. 1917. Der Erhaltungsgrund der Myrmekophilie. Zeitschrift für induktive Abstammungsund Vererbungslehre 18: 44-46, 71-72.

Low, A.B. \& A.G. ReBelo (eds.). 1996. Vegetation of South Africa, Lesotho and Swaziland. Pretoria: Department of Environmental Affairs \& Tourism.

NEw, T.R. 1997. Butterfly conservation. Melbourne: Oxford University Press.

OwEn-Johnston, N.K. 1991. Thoughts and observations on the genus Poecilmitis Butler (Lepidoptera: Lycaenidae) in the Transvaal. Metamorphosis 2(3): 49-50.

PIERCE, N.E. 1984. Amplified species diversity: a case study of an Australian lycaenid butterfly and its attendant ants Pp. 198-200. In: ACKERY, P. \& R. VAne-Wright (eds.). The biology of butterflies. London: Academic Press.

Pierce, N.E. \& P.S. MEAD. 1981. Parasitoids as selective agents in the symbiosis between lycaenid butterfly larvae and ants. Science 211: 1185-1187.
Pierce, N.E., R.L. Kitching, R.C. Buckley, M.F.J. TAYLOR \& K.F. BENBOW. 1987. The costs and benefits of co-operation between the Australian lycaenid butterfly Jalmenus evagoras and its attendant ants. Behavioural Ecology and Sociobiology 21: 237-248.

Pierce, N.E., M.F. Braby, A. Heath, D.J. Lohman, J. Mathew, D.B. Rand \& M.A. Travassos. 2002. The ecology and evolution of ant association in the Lycaenidae. Annual Reviews of Entomology 47: 733-771.

Pringle, E.L., G.A. Henning \& J.B. Ball (eds.). 1994. Pennington's butterflies of Southern Africa. Kaapstad: Struik.

Prins, A.J. 1978. Hymenoptera. Pp. 825-872. In: Werger, M.J.A. (ed.). Biogeography and ecology of Southern Africa. The Hague: Junk.

Retief, E. \& P.P.J. Hermann. 1997. Plants of the northern provinces of South Africa: keys and diagnostic characters. Pretoria: National Botanical Institute.

Roos, P. \& G.A. Henning. 2000. The Heidelberg Copper Butterfly. African Wildlife 54(2): 24-27.

Schlosz, M. \& P. Schlosz. 1990. A 'sound' observation. Metamorphosis 27: 24-25.

Schlosz, M. 1991. The call of pupae. Metamorphosis 2(2): 19-20.

Thomann, H. 1901. Schmetterlinge und Ameisen. Beobachtung über einer Symbiose zwischen Lycaena argus L. und Formica cinerea Mayr. Jaresbericht der Naturforschenden Gesselschaft Graubündens 44:1-40.

Thomas, J.A., G.W. Elmes, J.C. Wardlaw \& M. WOYCIECHOWSKI. 1989. Host specificity among Maculinea butterflies in Myrmica ant nests. Oecologia 79(4): 452-457.

WiLliams, M.C. 1996. Studying the early stages of Lepidoptera in Southern Africa. Metamorphosis 7(2): 56-64. 